\title{
Antioxidant and antibacterial activity of Ipomoea mauritiana Jacq.: a traditionally used medicinal plant in Bangladesh
}

\author{
Istiak Alam, Shaekh Forid ${ }^{1,2}$, Miah Roney², Fadhlizil Fasihi Mohd Aluwi² and Moyeenul Huq ${ }^{1,3^{*}}$ (D)
}

\begin{abstract}
Background: In an attempt to explore the scientific basis for the pharmacological benefits the antioxidant and antimicrobial activities of Ipomoea mauritiana whole plant methanol extract were assessed.

Methods: The total phenolic and flavonoid content were determined using standard method while antioxidant activity was determined by DPPH free radical scavenging activity method. The antimicrobial activity was evaluated by disk diffusion method and compared with standard kanamycin ( $30 \mu \mathrm{g} / \mathrm{disc})$.

Results: The results revealed that I. mauritiana extract contains tannin, saponin, terpenoids, alkaloid and flavonoids. In DPPH, ascorbic acid and extract showed highest scavenging activity and it was $90.96 \%$ at concentration $800 \mu \mathrm{g} /$ $\mathrm{mL}$ and I. mauritiana methanol extract showed $72.28 \%$ at a concentration of $800 \mu \mathrm{g} / \mathrm{mL}$. The extract was able to reduce the stable free radical DPPH with an $\mathrm{IC}_{50}$ of $275.084 \mu \mathrm{g} / \mathrm{mL}$ while that of ascorbic acid was $230.09 \mu \mathrm{g} / \mathrm{mL}$. Total phenolic constituent of the extract was $59.302 \pm 3.289 \mathrm{mg} / \mathrm{g}$ as gallic acid equivalent. The flavonoid content of methanolic extract of I. mauritiana was $27.212 \mathrm{mg}$ of QE/g. In case of antimicrobial screening, crude extracts of I. mauritiana showed notable antibacterial activity against tested microorganisms. The extract and standard showed the highest mean zone of inhibition ranging from 13 to $19 \mathrm{~mm}$ and 37 to $42 \mathrm{~mm}$, respectively at a concentration of $400 \mathrm{\mu g} /$ disc and against the gram positive bacteria (Bacillus cereus-19.25 mm) showed highest zone of inhibition.
\end{abstract}

Conclusions: The results indicate that I. mauritiana possesses considerable antioxidant and antimicrobial activity.

Keywords: Ipomoea mauritiana, Antioxidant activity, Antimicrobial activity

\section{Introduction}

Ipomoea mauritiana (I. mauritiana) Jacq. (Synonyms: Ipomoea digitata; Ipomoea eriosperma; Ipomoea paniculata; Convolvulus paniculatus) is a vine of the Convolvulaceae family. The plant has ethnomedicinal importance and found in many parts of the world. In Ayurvedic industries, I. mauritiana is popularly used as "Vidari" instead of the permitted raw drug Pueraria tuberose (Roxb. ex Willd). The Ayurvedic Pharmacopoeia of India

\footnotetext{
* Correspondence: moyeenul.rph@uap-bd.edu

'School of Science and Engineering, Department of Pharmacy, Southeast University, Dhaka, Bangladesh

${ }^{3}$ School of Medicine, Department of Pharmacy, University of Asia Pacific, 74/ A, Green Road, Dhaka, Bangladesh

Full list of author information is available at the end of the article
}

correlates I. mauritiana as Kshiravidari. Tubers are used in almost 45 Ayurvedic formulations, and in many instances also used as single drug. This is also an important component of the popular ayurvedic formulation Chyavanaprasha [1]. Traditionally the tubers are also extensively used by local communities in different parts of Bangladesh to treat various ailments including pain in spinal cord, to increase breast milk, body strength and sperm count, to control tuberculosis, as blood purifier in jaundice and to treat biliary disorders [2-5]. The leaves are also used to treat leucorrhea and diabetes with obesity and in infrequent urination by the folk medicine practitioners of Kurigram and Jhalokati districts of Bangladesh [6].

\section{Springer Open}

(c) The Author(s). 2020 Open Access This article is licensed under a Creative Commons Attribution 4.0 International License, which permits use, sharing, adaptation, distribution and reproduction in any medium or format, as long as you give appropriate credit to the original author(s) and the source, provide a link to the Creative Commons licence, and indicate if changes were made. The images or other third party material in this article are included in the article's Creative Commons licence, unless indicated otherwise in a credit line to the material. If material is not included in the article's Creative Commons licence and your intended use is not permitted by statutory regulation or exceeds the permitted use, you will need to obtain permission directly from the copyright holder. To view a copy of this licence, visit http://creativecommons.org/licenses/by/4.0/. 
The pharmacological investigations reported analgesic, hypoglycemic, hypocholesterolemic, and hepatoprotective activities of I. mauritiana tuber root [7, 8]. Additionally, the antibacterial activity against Escherichia coli which caused catheter associated urinary tract infections has also been reported by Pavan [9]. A number of phytochemical have been isolated from I. mauritiana tuber root methanol extracts which includes taraxerol, taraxerol acetate, $\beta$ sitosterol, scopoletin and 7-O- $\beta$-D-glycopyranosylscopoletin (scopolin) [10]. Literature showed that, scopoletin isolated from Lasianthus lucidus possessed antibacterial activity against Pseudomonus aerigenosa [11]. Plants are major source of natural antioxidants that can serve as possible drug candidates for different chronic ailments such as neurological diseases, swelling and diabetes [12, 13]. The wide range of potential benefits of natural antioxidants has increased the curiosity largely in medicine to ascertain new molecules to combat oxidative stress caused by free radicals [13].

Infective microbes are one of the major public health threats causing morbidity and mortality worldwide [14]. Several life-threatening microorganisms have now become resistant to many commercial antibiotics [15]. Novel, safe, potent and wide-spectrum antimicrobial molecules are therefore urgently needed [16]. Even though the plant has been widely used as traditional medicine, however there is inadequate scientific evidence on the potential benefits of the whole plant. Therefore, the current study was designed to determine the antioxidant and antimicrobial activities of I. mauritiana whole plant methanol extract.

\section{Materials and methods Plant collection}

I. mauritiana was collected from Tangail district of Bangladesh in July 2018 and was identified by Bangladesh National Herbarium. The collected plants (as a whole) were cleaned using tap water to remove the soil and washed with distilled water followed by shade drying. The dried plants were grounded into a fine powder.

\section{Plant extract preparation}

Powdered whole plant material having a weight of about $50 \mathrm{~g}$ were taken in one amber glass container and soaked in $500 \mathrm{~mL}$ methanol, for 3 days with occasional shaking and stirring. The extractive was then filtered using Whatman filter paper number 1 to attain a clear filtrate. The filtrate extract was concentrated and dried in vacuum at $40{ }^{\circ} \mathrm{C}$ and stored at $4{ }^{\circ} \mathrm{C}$ until further use.

\section{Preliminary phytochemical screening}

The presence of different phytochemicals such as alkaloid, steroids, glycosides, flavonoid, tannins, saponin, and terpenoids in crude methanol extract was determined following standard methods $[17,18]$. Any color change or precipitation formation indicated positive reactions to these tests.

\section{Test for steroids and Triterpenoids}

In the extract solution, few drops of acetic anhydride added and boiled. After cooling, concentrated sulphuric acid was slowly poured into the test tube. Formation of violet to blue or green color (Liebermann-Burchard reaction for steroid) indicated the positive reaction. Formation of green color of the upper layer and reddish- brown color in the bottom layer confirmed a positive test for steroids and terpenoids respectively $[17,18]$.

\section{Test for glycosides}

The plant extract solution was dissolved in a mixture of glacial acetic acid (5\%) and Ferric chloride solution and one or two drop of concentrated sulphuric acid was added. A brown ring or violet ring or greenish ring formation coloration indicated a positive test for glycosides [19].

One $\mathrm{mL}$ of distilled water was added to 10 drops of the extract dissolved in isopropyl alcohol $(20 \mathrm{mg} / \mathrm{mL})$ in a test-tube. The tube was shaken vigorously and observed for persistent froth formation and allowed to stand for $10 \mathrm{~min}$. A positive result indicate a forth formation which is stable as long as $15 \mathrm{~min}$ [19].

\section{Test for alkaloids}

Few drops of Mayer's reagent (potassium mercuric iodide solution) was mixed with I. mauritiana extract solution. A yellowish-white like precipitation indicates a positive reaction for the presence of such metabolites [19].

\section{Ferric chloride test for tannins}

The plant extract solution of $10 \mathrm{mg}$ was dissolved in ethanol $(1 \mathrm{~mL})$. Then distilled water $(2 \mathrm{~mL})$ was added followed by 4 drops of ferric chloride aqueous solution $(10 \% \mathrm{w} / \mathrm{v})$. The occurrence of phenols was confirmed by the development of dark blue or green color [20].

\section{Total phenolic content}

Total phenolic content of $I$. mauritiana extract was measured using a Folin-Ciocalteu colorimetric method spectrophotometrically as described by Idowu [21] with slight modification. Gallic acid was used as standard (concentration: 6.25-200 $\mu \mathrm{g} / \mathrm{mL}$ ) while $I$. 
mauritiana whole plant extract was $200 \mu \mathrm{g} / \mathrm{mL}$. Firstly, $1 \mathrm{~mL}$ of the extract or standard gallic acid solution was used in screw cap tube and $5 \mathrm{~mL}$ of FolinCiocalteu reagent was added. Then, $4 \mathrm{~mL}(7.5 \%)$ of anhydrous sodium carbonate was added followed by 30 in incubation at $40^{\circ} \mathrm{C}$. The vehicle solvent was used as blank solution. UV absorbance was taken with a UV-VIS spectrophotometer (Shimadzu, Japan) at $765 \mathrm{~nm}$. Total phenolic content was calculated as gallic acid equivalent (GAE) using the equation as follows:

$$
\mathrm{C}=(\mathrm{c} \times \mathrm{V}) / \mathrm{m}
$$

Where $\mathrm{C}=$ Total phenolics $(\mathrm{mg} / \mathrm{g}$ plant extract in GAE), $\mathrm{c}=$ concentration of sample obtained from calibration curve $(\mathrm{mg} / \mathrm{mL}), \mathrm{V}=$ volume of the sample, and $\mathrm{m}=$ sample weight $(\mathrm{g})$.

\section{Total flavonoid content}

To determine the total flavonoid content, the method of Rahman [22] was adopted, quercetin was the standard and different concentrations were used $(6.25-200 \mu \mathrm{g} / \mathrm{mL})$ while I.mauritiana methanol extract was $200 \mu \mathrm{g} / \mathrm{mL}$. Initially, in a volume of $1 \mathrm{~mL}$ of extract or $1 \mathrm{~mL}$ quercetin solution of different concentrations, $3 \mathrm{~mL}$ of methanol was added. After that, $200 \mu \mathrm{L}$ of $10 \%$ aluminum chloride and $200 \mu \mathrm{L}$ of $1 \mathrm{M}$ potassium acetate solution were added followed by the addition of $5.6 \mathrm{~mL}$ distilled water. Then the mixture incubated at room temperature for $30 \mathrm{~min}$. Absorbance at $415 \mathrm{~nm}$ was recorded against the blank (water). The total flavonoid content was calculated as per the formulae bellow:

$$
\mathrm{C}=(\mathrm{c} \times \mathrm{V}) / \mathrm{m}
$$

Where $\mathrm{C}=$ Total flavonoid content $(\mathrm{mg} / \mathrm{g}$ plant extract in Quercetin), c = concentration of sample obtained from calibration curve $(\mathrm{mg} / \mathrm{mL}), \mathrm{V}=$ volume of sample, and, $\mathrm{m}=$ sample weight (g). Measurement was taken triplicate.

\section{DPPH radical scavenging activity}

To determine the antioxidant activity, the method of described by Braca [23] was adopted with slight modification. At first, $100 \mu \mathrm{L}$ of plant extract and different concentrations of standard (ascorbic acid) were taken in test tubes. Then, $3 \mathrm{~mL}$ of $0.004 \%$ DPPH (2,2-diphenyl-1-picrylhydrazyl) solution in ethanol was added to each test tube followed by 30 min incubation. Later absorbance was taken at 517 $\mathrm{nm}$ spectrophotometically against methanol (blank).
The absorbance values were used to calculate the percentage of antioxidant activity (\% inhibition) using the formula below:

$$
\text { \%Scavenging }=\left\{\left(\mathrm{A}_{0}-\mathrm{A}_{1}\right) / \mathrm{A}_{0}\right\} \times 100 .
$$

Where $\mathrm{A}_{0}=$ Absorbance of DPPH solution only; $\mathrm{A}_{1}=$ Absorbance in the presence of test sample and standard ascorbic acid in DPPH solution. Measurement was taken triplicate.

\section{Antimicrobial activity of I. mauritiana Microorganisms}

Four gram-positive and six gram-negative bacteria were selected as test organisms. Gram positive; Bacillus cereus, Bacillus subtilis, Sarcina lutea, Staphylococcus aureus and Gram negative; Escherichia coli, Salmonella typhi, Salmonella paratyphi, Pseudomonas aeruginosa, Vibrio parahemolyticus and Shigella dysenteriae were used for antimicrobial activity test. Each of the stock cultures was collected as pure culture from the Institute of Nutrition and Food Science (INFS), University of Dhaka, Bangladesh.

\section{Antibacterial activity}

Disk diffusion method was used to perform the antibacterial test [24]. The sample solutions (400 and $200 \mu \mathrm{g} /$ $\mathrm{mL}$ ) were made by dissolving in methanol. Sterilized and dried filter paper discs $(6 \mathrm{~mm}$ diameter $)$ were then soaked in the crude extracts ( 400 and $200 \mu \mathrm{g} / \mathrm{mL} /$ disc) using micropipette and the solvent residue evaporated to dryness. Kanamycin $(30 \mu \mathrm{g} / \mathrm{disc})$ and blank discs (soaked with methanol followed by evaporation) were positive and negative control, respectively. The plates were inverted and refrigerated at $4{ }^{\circ} \mathrm{C}$ for $24 \mathrm{~h}$ for maximum diffusion. The following day plates were placed in the incubator at $37^{\circ} \mathrm{C}$ for another $24 \mathrm{~h}$ for optimum bacterial growth. The antimicrobial activity was observed with inhibited growth of the microorganisms giving a clear, distinct zone of inhibition around the discs. Finally, the diameter of zone of inhibition was measured. The data was obtained from three individual experiments $(n=3)$.

\section{Statistical analysis}

A statistical analysis was used to interpret the antimicrobial and antioxidant results. The experiment was conducted in completely randomized design with 3 replicates. The results are presented as means \pm standard error of means using MS excel [25].

\section{Result and discussion}

The results of preliminary phytochemical screening of $I$. mauritiana are presented in Table 1 . Results revealed that 
Table 1 Phytochemical screening of I. mauritiana

\begin{tabular}{lll}
\hline No. & Types of phytochemical constituents & Phytochemical composition (Methanolic extract) \\
\hline 1. & Terpenoids & + \\
2. & Saponins & + \\
3. & Flavonoids & - \\
4. & Glycosides & + \\
5. & Steroids & + \\
6. & Alkaloids & + \\
\hline
\end{tabular}

$(+)=$ Present,$(-)=$ Absent

the methanolic extract of $I$. mauritiana contains terpenoids, saponins, flavonoids, steroids, and alkaloids. The presence of these classes of compounds of this plant could be responsible for its various medicinal uses $[26,27]$.

On the other hand, the total phenolic content of $I$. mauritiana was evaluated as expressed by gallic acid equivalents per gram of extract which was found as $59.302 \pm 3.289 \mathrm{mg}$ of $\mathrm{GAE} / \mathrm{g}$. The value was obtained from regression equation of the calibration curve $(y=$ $0.004 x+0.105 ; r^{2}=0.992$ ) as shown in Fig. 1. Subsequently, the total flavonoid content of methanol extract of I. mauritiana was $27.212 \pm 0.51 \mathrm{mg}$ of QE/g which was obtained from the regression equation $(y=0.003 x+$ 0.023; $\left.r^{2}=0.995\right)$ as shown in Fig. 2 .

Similarly, DPPH free radical scavenging activity of I. mauritiana and ascorbic acid is shown in the Table 2. Both ascorbic acid and I. mauritiana methanolic extract showed dose dependent activity. Among the eight different concentrations $(6.25,12.5$, $25,50,100,200,400$ and $800 \mu \mathrm{g} / \mathrm{mL}$ ) ascorbic acid showed $\quad 14.05 \pm 1.64, \quad 16.66 \pm 1.55, \quad 20.47 \pm 1.47$, $27.20 \pm 1.64, \quad 42.76 \pm 1.64, \quad 74.89 \pm 1.63, \quad 87.82 \pm 1.73$ and $90.96 \pm 1.64 \%$ scavenging activity respectively while, I. mauritiana methanol extract showed $20.68 \pm 1.15, \quad 26.50 \pm 1.64, \quad 31.92 \pm 1.80, \quad 38.45 \pm 1.89$, $48.99 \pm 1.73, \quad 59.03 \pm 1.86, \quad 66.86 \pm 1.78$ and $72.28 \pm$ $1.8 \%$ scavenging activity respectively. In addition, the $\mathrm{IC}_{50}$ of ascorbic acid and methanolic extract were

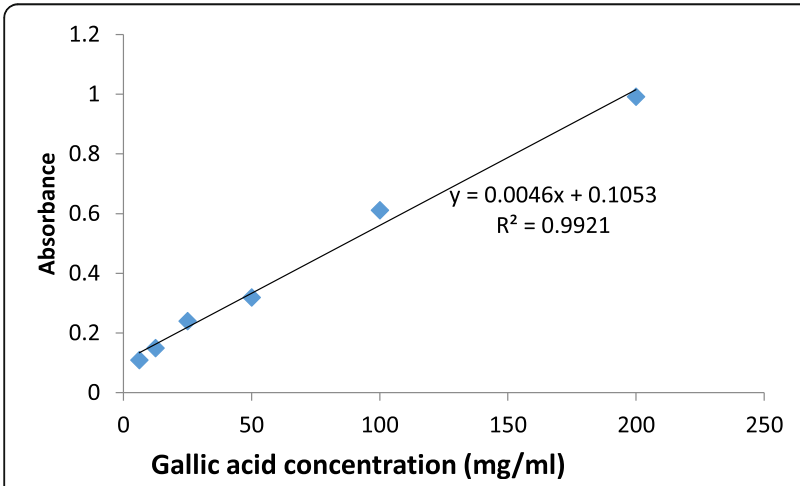

Fig. 1 Concentration-response curve of gallic acid standard at $765 \mathrm{~nm}$
$230.09 \mu \mathrm{g} / \mathrm{mL}$ and $275.084 \mu \mathrm{g} / \mathrm{mL}$ respectively as shown in Table 2. The DPPH scavenging activity of I. mauritiana methanol extract was lesser than that of standard ascorbic acid. The $\mathrm{IC}_{50}$ value denotes the minimum sample concentration required to scavenge $50 \%$ free radical. The antiradical activity of the extract may be due to their high content of phenols, as polyphones which contribute to the antioxidant activity in living systems by chelation and electron transfer or hydrogen donating ability of hydroxyl groups in ortho- and para- positions thus neutralizing the free radicals $[28,29]$.

The results of antibacterial activity of the extract and standard kanamycin with respect to each of the test organisms are presented in Table 3. The mean zone of inhibition of kanamycin was between 37 to $42 \mathrm{~mm}$ and the extract which was between 13 to 19 $\mathrm{mm}$, respectively at a concentration of $400 \mu \mathrm{g} /$ disc. Zone of inhibition of standard was larger than extract. The extract showed the highest zone of inhibition against the gram positive; Bacillus cereus (19.25 \pm $1.020 \mathrm{~mm})$ and Sarcina lutea $(18.5 \pm 0.0813 \mathrm{~mm})$ and gram negative Shigella boydii $(18.25 \pm 3.06 \mathrm{~mm})$ and had no activity against Escherichia coli. Gram positive strains were more sensitive to the extract than the gram negative ones. However, the extract had the lowest antibacterial effect to Pseudomonas aureus. These results indicate that I. mauritiana extract is

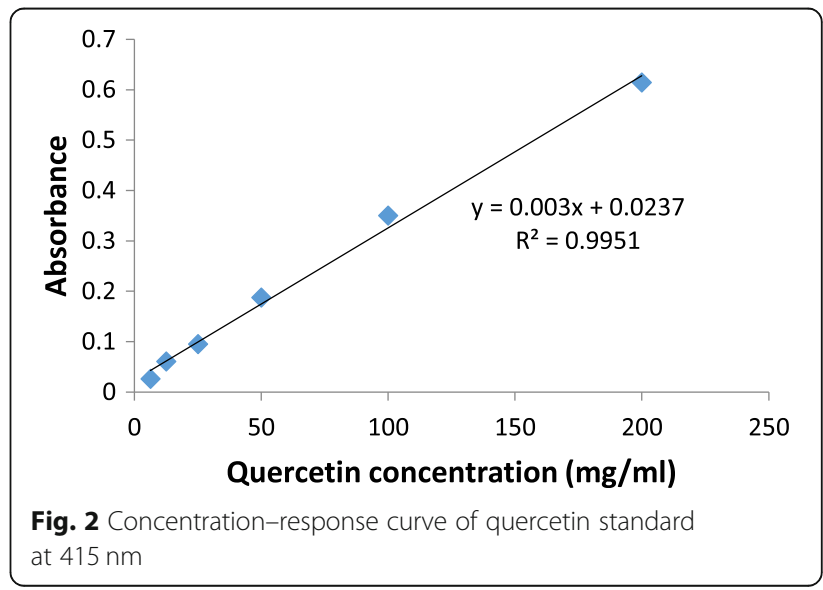


Table 2 DPPH free radical scavenging activity of ascorbic acid and I. mauritiana extract

\begin{tabular}{lll}
\hline $\begin{array}{l}\text { Concentration } \\
\mu \mathrm{g} / \mathrm{mL})\end{array}$ & \multicolumn{2}{l}{ \% of scavenging of DPPH (Mean \pm STD) } \\
\cline { 2 - 3 } & Ascorbic acid (Standard) & I. mauritiana extract \\
\hline 6.25 & $14.055 \pm 1.637$ & $20.682 \pm 1.147$ \\
12.5 & $16.665 \pm 1.551$ & $26.506 \pm 1.639$ \\
25 & $20.478 \pm 1.471$ & $31.927 \pm 1.803$ \\
50 & $27.205 \pm 1.636$ & $38.453 \pm 1.885$ \\
100 & $42.768 \pm 1.635$ & $48.996 \pm 1.731$ \\
200 & $74.897 \pm 1.636$ & $59.036 \pm 1.856$ \\
400 & $87.821 \pm 1.726$ & $66.867 \pm 1.784$ \\
800 & $90.963 \pm 1.638$ & $72.289 \pm 1.803$ \\
$\mathcal{I}_{50}(\mu \mathrm{g} / \mathrm{mL})$ & 230.09 & 275.084 \\
\hline
\end{tabular}

active against both bacterial strains as compared to standard antibiotic, kanamycin.

Plant has been a very significant source of medicine for decades and many plants have been tested for their potential bioactive compounds [30].

Free radicals are significant contributor in many pathological manifestations. Antioxidants can maintain good health and protect, either by counteracting these free radicals or defending the body's antioxidant defense mechanisms. Plants and herbs, being the potential sources for a number of antioxidants in addition to their therapeutic properties, have appealed the concern of scientific community to meet up the growing interest for raw materials with potential natural antioxidant compounds. Phenolic or polyphenolic compounds are one of the major classes of compounds having strong antioxidant properties. The antioxidative action of phenolic compounds is primarily due to their redox properties, [31, 32] which can hydrolyze and neutralize free radicals, purify singlet and triplet oxygen, or decompose peroxides.
On the other hand, ongoing demand for new antibiotic is present due to the sustained emergence of infectionresistant strains. About $80 \%$ of the drugs available in many developing countries originated from medicinal plants. In the industries of many countries plants comprise the raw material for processes that synthesizes pure chemical derivatives [33].

In the present study, prominent antioxidant activity was observed for the whole plant extract of I. mauritiana with potential antibacterial activity against a number of Gram (+) ve and Gram (-) ve bacteria. Different parts of the plant may vary with their antioxidant activity. For instance, a study revealed that, the root and stem bark, leaf and flower parts of Tabebiua pallida methanol extract were tested for antioxidant activity where the leaf extract was found to show highest antioxidative and free radical scavenging property which was also rich in total phenols and flavonoid contents [34]. The current study thus was conducted with the whole plant of $I$. mauritiana. It is clear from the results that, total phenolic and flavonoid contents and DPPH scavenging activity signifies the potential bioactivity of I. mauritiana. This result is consistent with the report of Sulaiman [35]. Moreover, phenolic compounds demonstrates potential antibacterial activity. Rahman and collegues stated that, 3,4-dihydroxybenzoic acid obtained from Cananga odorata was active against a number of Gram (+) and Gram (-) bacteria [36].

In the same way, the antibacterial activity of $I$. mauritiana against gram positive bacteria such as Bacillus cereus, Bacillus subtilis, Sarcina lutea, Staphylococcus aureus and gram negative bacteria such as Escherichia coli, Salmonella typhi, Salmonella paratyphi, Pseudomonas aeruginosa, Vibrio parahemolyticus and Shigella dysenteriae was evaluated. These are important pathogens and can rapidly develop antibiotic resistance as

Table 3 Antibacterial activity of I. mauritiana using the disk diffusion method

\begin{tabular}{|c|c|c|c|c|}
\hline \multirow{2}{*}{$\begin{array}{l}\text { Bacterial } \\
\text { strains }\end{array}$} & \multirow[t]{2}{*}{ Test organisms } & \multicolumn{3}{|l|}{ Zone of inhibition (mm) } \\
\hline & & I. mauritiana (400 $\mu \mathrm{g} /$ disc) & I. Mauritiana (200 $\mu \mathrm{g} / \mathrm{disc})$ & Kanamycin $(30 \mu \mathrm{g} / \mathrm{disc})$ \\
\hline \multirow[t]{4}{*}{ Gram positive } & Bacillus cereus & $19.25 \pm 1.020$ & - & $42.56 \pm 0.816$ \\
\hline & Bacillus subtilis & $14.25 \pm 0.612$ & - & $37.86 \pm 1.224$ \\
\hline & Staphylococcus aureus & - & - & $41.25 \pm 0.186$ \\
\hline & Sarcina lutea & $18.5 \pm 0.0813$ & - & $40.50 \pm 0.408$ \\
\hline \multirow[t]{6}{*}{ Gram negative } & Escherichia coli & - & - & $39.66 \pm 0.471$ \\
\hline & Pseudomonas aureus & $13 \pm 0.816$ & - & $40.05 \pm 0.754$ \\
\hline & Salmonella paratyphi & $15.15 \pm 0.122$ & - & $41.48 \pm 0.465$ \\
\hline & Shigella dysenteriae & - & - & $42.82 \pm 0.275$ \\
\hline & Shigella boydii & $18.25 \pm 3.06$ & - & $41.95 \pm 0.568$ \\
\hline & Vibrio parahemolyticus & $16 \pm 0.816$ & - & $38.52 \pm 0.437$ \\
\hline
\end{tabular}

Note: The diameter of zone of inhibition are expressed as mean \pm SD. $(n=3)$; a diameter less than 8 mm was considered inactive. Zone of inhibition (mm) determined after $24 \mathrm{~h}$ of incubation at $37^{\circ} \mathrm{C}$ 
antibiotic use increases. However, a previous report stated that, the leaf freeze dried extract of I. mauritiana did not show any activity against Streptococcus mutans, S. mitis, Staphylococcus aureus, and a fungi Candida albicans in both agar disk and agar well diffusion tests [37]. This study reveals the promise of antibacterial activity of I. mauritiana against gram positive bacteria in particular.

\section{Conclusion}

The results demonstrated that the methanolic extract of $I$. mauritiana Jacq shown antioxidant and antimicrobial activity. These findings could be a scientific evidence to use this plant as a potential source of antioxidant and antibacterial agents. However, future studies are necessary to determine the mechanisms of these pharmacologic properties. Moreover, phytochemicals characterization of possible bioactive compounds in I. mauritiana Jacq is also required.

\section{Acknowledgments}

The authors would like to thank the Institute of Nutrition and Food Science (INFS), University of Dhaka, for generously providing the test organisms.

\section{Authors' contributions}

IA performed the extraction and antioxidant study and analyzed the data. MSF performed the antibacterial study. MSF and RM drafted the manuscript and MFFMA edited the manuscript. AKMMH planned and supervised the work and finalized the manuscript. All authors approved the final version of the manuscript.

\section{Funding}

None.

\section{Availability of data and materials}

All data generated and analyzed are present in this manuscript

\section{Ethics approval and consent participate \\ None.}

\section{Consent for publication}

Not applicable.

\section{Competing interests}

Authors have no conflict of interest.

\section{Author details}

${ }^{1}$ School of Science and Engineering, Department of Pharmacy, Southeast University, Dhaka, Bangladesh. 'Faculty of Industrial Sciences \& Technology, Universiti Malaysia Pahang, Lebuhraya Tun Razak, 26300, Gambang, Pahang, Malaysia. ${ }^{3}$ School of Medicine, Department of Pharmacy, University of Asia Pacific, 74/A, Green Road, Dhaka, Bangladesh.

Received: 2 January 2020 Accepted: 26 May 2020

Published online: 30 May 2020

\section{References}

1. Devaiah K, Paranthaman S. Development of randomly amplified polymorphic DNA based SCAR marker for identification of Ipomoea mauritiana Jacq (Convolvulaceae). Evid Based Comple Alt Med. 2011;868720: $1-6$.

2. Anzumi H, Rahman S, Islam MA, Rahmatullah M. Uncommon medicinal plant formulations used by a folk medicinal practitioner in Naogaon district, Bangladesh. World J Pharm Pharm Sci. 2014;3(12):176-88.
3. Azad AK, Mahmud MR, Parvin A, Chakrabortty A, Akter F, Moury SI, Anny IP, Tarannom SR, Joy SK, Chowdhury SY, Akter S, Rahmatullah M. Ethnomedicinal surveys in two Mouzas of Kurigram district, Bangladesh. World J Pharm Pharm Sci. 2014;3(10):1607-20.

4. Jahan N, Khan A, Hasan MN, Hossain MU, Das U, Sultana S, Rahmatullah M. Ethnomedicinal plants of fifteen clans of the Garo tribal community of Madhupur in Tangail district, Bangladesh. Am Eur J Sustain Agric. 2013;7: 188-95.

5. Walid R, Suvro KFA, Harun-or-Rashid M, Mukti M, Rahman S, Rahmatullah M. Ethnomedicinal plants of folk medicinal practitioners of two villages in Bagerhat district of Bangladesh. Am Eur J Sustain Agric. 2013;7(2):61-74.

6. Rahmatullah M, Nuruzzaman M, Hossan MS, Khatun MA, Rahman MM, Jamal F, Harun-Or-Rashid M, Nasrin D, Seraj S, Jahan R. An ethnomedicinal survey of folk medicinal practitioners of Shitolpara village, Jhalokati district, Bangladesh. Adv Nat Appl Sci. 2010;4(1):85-92.

7. Islam S, Ahmed MR, Al-Mahamud R. Callus extract of Ipomoea mauritiana show analgesic and antihyperglycemic activity in Swiss albino mice. J Appl Pharm Sci. 2015;5(10):44-7.

8. Moushumi JS. Hypoglycemic, hypocholesterolemic and hypotriglyceridemic activity of tuber roots of Ipomoea mauritiana Jaca (Convolvulaceae) when administered to rats. Adv Nat Appl Sci. 2010;4(2):174-6.

9. Pavan HV, Murthy DSM, Devi DNL. Isolation and identification of urinary catheter associated bacteria and study of in vitro antibacterial activity of methanolic and petroleum ether leaf extracts of Ipomoea mauritiana Jacq against bacteria isolated from urinary catheters. Int J Herb Med. 2017;5(5):216-20.

10. Dharmaratne HRW, Jayasinghe ULB, Weerawardhena WDPP, Herath HMTB, Fujimoto Y. Chemical investigation of Ipomoea mauritiana. ACGC Chem Res Commun. 1997;6:39-41.

11. Tiwtawat N, Markus B, Henrik B, Kwankamol T, Wichai S, Srunya V. Scopoletin from Lasianthus lucidus Blume (Rubiaceae): a potential antimicrobial against multidrug-resistant Pseudomonas aeruginosa. J Appl Pharm Sci. 2018;8:001-6.

12. Venkatesan A, Kathirvel A, Prakash S. Sujatha V, antioxidant, antibacterial activities and identification of bioactive compounds from Terminalia chebula bark extracts. Free Radic Ant. 2017;7(1):44-50.

13. Paliwal SK, Sati B, Faujdar S, Sharma S. Antioxidant and antibacterial activities of various extracts of Inula cuspidate (CB) Clarke stem Beni-Suef. Univ J Basic Appl Sci. 2017;6(2):97-105.

14. Natarajan D, Shivakumar MS, Srinivasan R. Antibacterial activity of leaf extracts of Biophytum sensitivum (L.) DC. J Pharm Sci Res. 2010;2(11):717-20.

15. Srinivasan R, Aruna A, Manigandan K, Pugazhendhi A, Kim M, Shivakumar MS, Natarajan D. Phytochemical, antioxidant, antimicrobial and antiproliferative potential of Elaeagnus indica. Biocatal Agric Biotechnol. 2019;20:101265.

16. Srinivasan R, Natarajan D, Shivakumar MS. Antimicrobial and GC-MS analysis of Memecylon edule leaf extracts. Inter J Cur Res. 2014;5:1-13.

17. Dev UK, Hossain MT, Islam MZ. Phytochemical investigation, antioxidant activity and anthelmintic activity of Mikania micrantha leaves. World J Pharm Res. 2015:4(5):121-33.

18. Hossain MT. Antioxidant, cytotoxicity, membrane stabilization and anthelmintic activity of ethanolic extract of Sarcochlamys pulcherrima leaves. Int J Green Herbal Chem. 2015;4:274-83.

19. Bhandary SK, Suchetha KN, Bhat VS, Sharmila KP, Bekal MP. Preliminary phytochemical screening of various extracts of Punica granatum peel whole fruit and seeds. Nitte Univ J Health Sci. 2012;2(4):35-8.

20. María R, Shirley M, Xavier C, Jaime S, David V, Rosa S, Jodie D. Preliminary phytochemical screening, total phenolic content and antibacterial activity of thirteen native species from Guayas province. J King Saud Univ Sci. 2018; 30(4):500-5.

21. Sagbo IJ, Afolayan AJ, Bradley G. Antioxidant, antibacterial and phytochemical properties of two medicinal plants against the wound infecting bacteria. Asian Pac J Trop Biomed. 2017;7(9):817-25.

22. Rahman MA, Chowdhury JMKH, Aklima J, Azadi MA. Leea macrophylla Roxb leaf extract potentially helps normalize islet of $\beta$-cells damaged in STZinduced albino rats. Food Sci Nutr. 2018;6(4):943-52.

23. Braca A, Tommasi ND, Bari LD, Pizza C, Politi M, Morelli I. Antioxidant principles from Bauhinia terapotensis. J Nat Prod. 2001;64(7):892-5.

24. Bauer AW, Kirby WMM, Sherris JC, Turck M. Antibiotic susceptibility testing by a standardized single disc method. Am J Clin Pathol. 1996;45:493-6.

25. Ansar M, Gulam M. Phenolic contents, antimicrobial and antioxidant activity of Olea ferruginea Royle (Oleaceae). BMC Complement Alt Med. 2018;18:173. 
26. Asolkar LV, Chopra RN. Second supplement to glossary of Indian medicinal plants with active principles. Publications \& Information Directorate; 1992.

27. Mishra SS, Datta KC. A preliminary pharmacological study of Ipomoea digitata Linn. Indian J Med Res. 1962;50:43-5.

28. Oyaizu M. Studies on products of browning reaction. Antioxidative activities of products of browning reaction prepared from glucosamine. Jpn J Exp Med. 1986;44(6):307-15.

29. Lapornik A, Prosek M, Wondra GA. Comparision of extracts prepared from plant byproducts using different solvents and extraction time. J Food Eng. 2005;71(2):214-22.

30. Rosy BA. Joseph H, Rosalie. Phytochemical, pharmacognostical, antimicrobial activity of Indigofera spalathoids Vahl (Fabaceae). Int J Biol Technol. 2010;1:12-5.

31. Galato D, Ckless K, Susin MF, Giacomelli C, Ribeiro-do-Valle RM, Spinelli A. Antioxidant capacity of phenolic and related compounds: correlation among electrochemical, visible spectroscopy methods and structureantioxidant activity. Redox Rep. 2001;6(4):243-50.

32. Zheng W, Wang SY. Antioxidant activity and phenolic compounds in selected herbs. J Agr Food Chem. 2001;49(11):5165-70.

33. Penso $\mathrm{G}$. The role of $\mathrm{WHO}$ in the selection and characterisation of medicinal plants. J Ethnopharmacol. 1980;2(2):183-8.

34. Rahman MM, Islam MB, Biswas M, Alam KAHM. In vitro antioxidant and free radical scavenging activity of different parts of Tabebuia pallida growing in Bangladesh. BMC Res Notes. 2015;8:621.

35. Sulaiman C, Sivadasan PG, Balachandran I. Identification of phenolic antioxidants in Ipomoea mauritiana jacq using spectrophotometric and mass spectroscopic studies. Avicenna J Phytomed. 2014:4(2):89-96.

36. Rahman MM, Lopa SS, Sadik G, Rashid H, Islam R, Khondkar P, Alam KAHM, Rashid A. Antibacterial and cytotoxic compounds from the bark of Cananga odorata. Fitoterapia. 2005;76:758-61.

37. Pochapski MT, Fosquiera EC, Esmerino LA, dos Santos EB, Farago PV, Santos FA, et al. Phytochemical screening, antioxidant, and antimicrobial activities of the crude leaves' extract from Ipomoea batatas (L.) lam. Phcog Mag. 2011;7:165-70

\section{Publisher's Note}

Springer Nature remains neutral with regard to jurisdictional claims in published maps and institutional affiliations.

\section{Submit your manuscript to a SpringerOpen ${ }^{\circ}$ journal and benefit from:}

- Convenient online submission

- Rigorous peer review

- Open access: articles freely available online

- High visibility within the field

- Retaining the copyright to your article

Submit your next manuscript at $\boldsymbol{\nabla}$ springeropen.com 